\title{
Analysis of Yield and Technological Gaps of Potato Production in Bihar
}

\author{
Dhiraj K. Singh*1, N.K. Pandey ${ }^{2}$, P. Kharumnuid ${ }^{3}$ and Raj Kumar Singh ${ }^{4}$ \\ ${ }^{1 *}$ ICAR-Research Complex for Eastern Region, Patna -800014, Bihar, India \\ ${ }^{2 \& 3}$ Division of Social Sciences, ICAR-Central Potato Research Institute, Shimla-171001, HP. India \\ ${ }^{4}$ ICAR- Central Potato Research Station, Patna-801506, Bihar, India \\ *Corresponding author: dhirajextension@gmail.com (ORCID ID: 0000-0002-7177-2927)
}

Received: $10-09-2019$

Revised: $20-01-2020$

Accepted: 22-02-2020

\begin{abstract}
The existence of large yield and technological gaps in different crops is a major problem faced by Indian agriculture. Potato being the most important vegetable of the country, also faces similar problem where actual yields are far below the potential yield. This study was attempted to analyze the yield and technological gap in potato production in Bihar. Data was collected from 90 farmers of Vaishali and Saran districts of Bihar using a structured interview schedule. The results revealed that the overall yield gap of 43.4 per cent existed in potato production in sampled area, which was largely due to the wide scale adoption of a local red skinned potato variety, Bhura aloo. The yield gap was maximum for marginal farmers (48.57\%) followed by small farmers. Intensity of adoption was highest for this local variety i.e. Bhura aloo (33.01\%) followed by Kufri Sindhuri (27.7\%), Kufri Pukhraj (12.64\%), Kufri Jyoti (6.83\%) and Lal Gulab (5.53\%). Large technological gap was observed with respect to the use of recommended dose of NPK fertilizers and pesticides by the farmers. Overall gap in input use per unit area was highest in case of potassium fertilizer (35.4\%) followed by nitrogenous fertilizers (27.6\%). This yield and technological gaps can be bridged by motivating and supporting farmers to adopt high yielding improved varieties and provision of effective extension services to enable farmers to use recommended level of fertilizers and pesticides.
\end{abstract}

\section{Highlights}

( Large gap in yield of potato was observed ranging from 30-50 per cent in Vaishali and Saran districts of Bihar mostly due to prevalence of local variety among farmers.

Keywords: Yield gap, technological gap, intensity of adoption, potato production, Bihar

The agriculture sector plays a very important role in Indian economy. It is the largest private sector occupation providing employment to more than half of Indian population mostly residing in rural areas. According to the 2011 census of India, 68.84\% of Indian population (around 83.31 crore) live in 6,40,867 different villages distributed all over India (MHA, 2011). Therefore, India's development is intimately linked with development of agriculture sector and improving income of farmers. The Government is also keen towards increasing income of farmers and improving their socio-economic status. This is obvious from the fact that the Govt. has set a target of doubling farmers' income by the year 2022-23 to promote farmers' welfare, reduce agrarian distress and bring parity between income of farmers and those working in non-farm sector (Chand, 2017). Increasing crop productivity is one of the important measures for improving farm income as large yield gap is observed in many parts of the country. As yields of cereals such as rice

How to cite this article: Singh, D.K., Pandey, N.K., Kharumnuid, P. and Singh, R.K. (2020). Analysis of yield and technological gaps of potato production in Bihar. Economic Affairs, 65(1): 51-56. 
and wheat are likely to level off or even decline in many regions of the world over the next decades because maximum achieved yields are closer to the crop potential yields (Lobell et al. 2009; Licker et al. 2010). Horticulture crops will play a definitive role in achieving the food and nutritional security across the world. Yield gap in horticulture crops is a major issue in India where actual yields are far below the potential yield. Potential yield is the yield of a cultivar when grown in an environment to which it is adapted, with optimal amounts of water and nutrients, and all biotic stresses effectively controlled. It is relevant to crops and environments where irrigation, the amount and distribution of rainfall, or a combination of irrigation and rainfall ensure that water deficits do not constrain yield (Licker et al. 2010; Haverkort and Struik, 2015).

Potato (Solanum tuberosum L.), the third most important food crop after rice and wheat, is consumed by over a billion people (Devaux et al. 2014). India is the second largest potato producing country in the world. As per estimates, India produced a record 48.6 million tonnes of potato during 2016-17. Potato is the most important vegetable in our country and contribute 27.3 per cent of total vegetable production (Singh et al. 2018). Most of the potato in India is consumed as vegetable. Uttar Pradesh (UP) is the highest potato producing state of the country followed by West Bengal and Bihar (DAC\&FW, 2018). With ever increasing population, Nearly 125 million $t$ of potato will be required from an enhanced area of 3.62 million ha with an average productivity of 34.5 t/ha during the year 2050 (CPRI, 2015). It will be a real challenge to increase potato productivity of India from current $22 \mathrm{t} / \mathrm{ha}$ to $34.5 \mathrm{t} / \mathrm{ha}$. Being a cash crop, potato cultivation is a profitable enterprise for farmers and marketed surplus can be as high as $97.3 \%$ in this crop leading to more income (Sinha and Singh, 2019). The yield of potato varies widely in plains, plateau and hilly regions due to difference in agro climatic conditions, soil types as well as farmers' practices. In Bihar, yield of potato is hovering around 19-20 t/ha since last $4-5$ years which is below the national productivity (Nearly 22 $\mathrm{t} / \mathrm{ha}$ ). Within Bihar also, yield is different in different agro- climatic zones. Keeping in mind these facts, current study was undertaken to analyse current status of potato productivity, varietal adoption pattern, extent of yield gap and technological gap of some important production input technologies in Bihar state of Eastern India.

\section{MATERIAL AND METHODS}

\section{Sampling procedure and sources of data}

This study was conducted in Vaishali and Saran districts of Bihar (Fig. 1). Both these districts are selected purposively since these were two top potato producing districts of North West regions (Agro climatic Zone I) of Bihar. Three blocks in each district (total six blocks) and 15 potato growers from each block were selected for data collection. Thus, the total sample size for this study was 90 farmers. Primary data was collected through survey method using a structured interview schedule and analyzed using suitable statistical tools. Secondary data was also collected from already published articles for data on area, production and productivity as well as yield data for demonstration yield and potential yield of a variety.

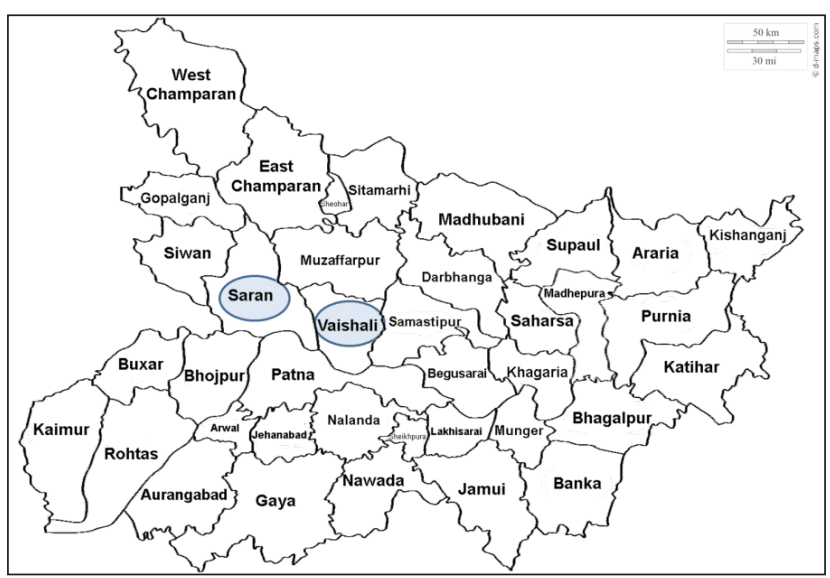

Fig. 1. Map showing the study areas

\section{Quantification of data}

The yield gap of potato in this study was estimated using methodology developed by the International Rice Research Institute (IRRI). The yield gap $\left(Y_{g}\right)$ is the quantitative differences between a base-line yield (normally taken as average farmers' yield) and either attainable (taken as experiment-based yield) or potential yield $\left(Y_{p}\right)$ over some specified spatial and temporal scale (Sadras et al. 2015). Potential yield was defined as the per hectare crop yield realized on the research station, demonstration plot yield $\left(Y_{d}\right)$ is defined as the per hectare yield realized 
on the Frontline Demonstration (FLD) plots and the Actual yield $\left(Y_{a}\right)$ was defined as the per hectare yield realized by the farmers on their field. The total yield gap (TYG) was computed as the difference between the potential yield $\left(Y_{p}\right)$ and the actual yield $\left(Y_{a}\right)$.

$$
\mathrm{TYG}=Y_{p}-Y_{a}
$$

Where,

$$
\begin{aligned}
& Y_{p}=\text { Potential yield } \\
& Y_{a}=\text { Actual yield }
\end{aligned}
$$

This total yield gap comprised of yield gap I and yield gap II. Yield Gap I (YG-I) is the difference between the potential yield $\left(Y_{p}\right)$ and yield of Frontline Demonstration plot yield $\left(Y_{d}\right)$. Yield data of Kufri Sindhuri in FLD plot in Bihar was taken as $Y_{d}$ for this study (CPRI Annual Report, 2017).

$$
\mathrm{YG}-\mathrm{I}=Y_{p}-Y_{d}
$$

Where, $Y_{d}=$ Demonstration plot yield

Yield Gap II (YG-II) is the difference between the demonstration plot yield $\left(Y_{d}\right)$ and the actual yield $\left(Y_{a}\right)$

$$
\mathrm{YG}-\mathrm{II}=Y_{d}-Y_{a}
$$

Use of local varieties instead of modern high yielding improved varieties can cause yield gap at farmer's field. So, both incidence (percentage of farmers adopting improved varieties) and intensity (percentage area under improved varieties) of adoption was worked out for different varieties.

The adoption of improved production technologies is vital for bridging the yield gap of the crops. Thus, we also analyzed the technological gap of five important production input technologies, namely, seed rate, recommended dose of Nitrogen, Phosphorus and Potassium and recommended dose of plant protection chemicals used to control late blight disease. Technological gap has been defined as the proportion of gap in the adoption of practices recommended and it is expressed in percentage (Ray et al. 1995). The technological gap of each technology was calculated by the following formula.

Technological Gap =

$\underline{\text { Recommended practice - Actual input use }}$ Recommended practice

\section{RESULTS AND DISCUSSION}

\section{Estimation of yield gap I \& II}

Based on analysis of data collected from farmers of Vaishali and Saran districts, yield gap I and II was estimated along with percentage yield gap (Table 1). It was observed that there was a significant difference in productivity of potato at demonstration plot and farmers' fields. The potential farm yield (yield of Frontline Demonstration plot) realized was $29.1 \mathrm{t} /$ ha which was nearly $6 \mathrm{t} /$ ha lesser than the potential yield. The actual average yield at sampled farms was even lesser at $19.8 \mathrm{t} / \mathrm{ha}$. It is inferred that there was 16.85 per cent of yield gap between potential yield and demonstration yield. The yield gap II which is the difference between the demonstration plot yield $\left(Y_{p}\right)$ and actual yield $\left(Y_{a}\right)$ was found to be 31.95 per cent. The total yield gap (TYG) observed is 43.43 per cent at overall level. Higher yield of potato at demonstration plot could be attributed to the fact

\begin{tabular}{|c|c|c|c|c|}
\hline \multirow[b]{2}{*}{ Particulars } & \multicolumn{3}{|c|}{ Size Groups } & \multirow[b]{2}{*}{$\begin{array}{l}\text { Overall } \\
(\mathrm{N}=90)\end{array}$} \\
\hline & $\begin{array}{l}\text { Marginal } \\
(<1 \text { ha }) \\
(n=44)\end{array}$ & $\begin{array}{l}\text { Small } \\
(1-2 \text { ha) } \\
(n=28)\end{array}$ & $\begin{array}{l}\text { Large } \\
(>2 \text { ha }) \\
(n=18)\end{array}$ & \\
\hline Potential yield ${ }^{*}\left(Y_{p}\right)$ & 35 & 35 & 35 & 35 \\
\hline $\begin{array}{l}\text { Potential farm yield } \\
\left(\text { FLD }^{* *} \text { yield }\right)\left(Y_{d}\right)\end{array}$ & 29.1 & 29.1 & 29.1 & 29.1 \\
\hline Actual yield $\left(Y_{a}\right)$ & 18.0 & 20.1 & 23.9 & 19.8 \\
\hline Yield gap I $\left(Y_{p}-Y_{d}\right)$ & 5.9 & 5.9 & 5.9 & 5.9 \\
\hline Per cent gap & 16.8 & 16.8 & 16.8 & 16.85 \\
\hline Yield gap II $\left(Y_{d}-Y_{a}\right)$ & 11.1 & 9.0 & 5.2 & 9.3 \\
\hline Per cent gap & 38.1 & 30.9 & 17.9 & 31.9 \\
\hline $\begin{array}{l}\text { Total yield gap } \\
\left(Y_{p}-Y_{a}\right)\end{array}$ & 17 & 14.9 & 11.1 & 15.2 \\
\hline Per cent gap & 48.6 & 42.6 & 31.7 & 43.4 \\
\hline
\end{tabular}
that cultivation practices are on scientific lines and carried out under the supervision of scientists.

Table 1: Yield gap in potato at sampled farms in Vaishali and Saran districts (yield in $\mathrm{t} / \mathrm{ha}$ )

* Taken as potential yield of most popular variety Kufri Sindhuri; ** Yield of Frontline Demonstration of Kufri Sindhuri in the study area.

Category wise analysis indicated highest yield gap in marginal farms (48.57\%) followed by small and large farms having 42.57 and 31.71 per cent yield gap respectively. Thus, yield gap is decreasing with increasing farm size. This may be due to better management of farms and optimum use of 
inputs by large farmers due to more availability of economic resources. Similar trend was observed in case of study of sugarcane crop in Bihar (Singh, 2015).

\section{Adoption pattern of improved potato varieties}

It is a known fact that the yield of a crop depends on its varietal attribute and it varies from variety to variety. Therefore, adoption pattern of improved potato varieties was studied in selected area to find out the possible reasons of yield gap (Table 2 \& Fig. 2).

Table 2: Incidence and intensity of adoption of different potato varieties in selected districts of Bihar

$$
(\mathrm{N}=90)
$$

\begin{tabular}{lll}
\hline Name of varieties & $\begin{array}{l}\text { Incidence of } \\
\text { adoption } \\
\text { adopters) }\end{array}$ & $\begin{array}{l}\text { Intensity of } \\
\text { adoption (\% area) }\end{array}$ \\
\hline Bhura aloo $^{*}$ & 40.85 & 33.01 \\
Kufri Sindhuri & 26.22 & 27.7 \\
Kufri Pukhraj & 6.20 & 12.64 \\
Kufri Jyoti & 6.50 & 6.83 \\
Lal Gulab & 6.50 & 5.53 \\
Kufri Lalit & 7.78 & 3.10 \\
Others & 5.95 & 11.19 \\
\hline
\end{tabular}

* This included a mix of various red colour local potato cultivars.

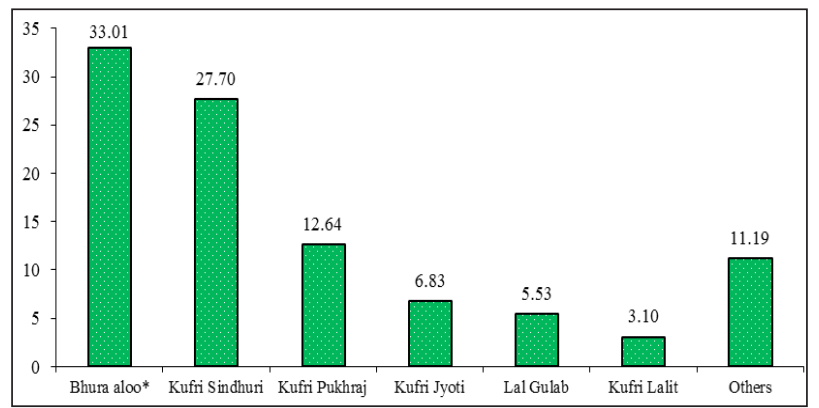

Fig. 2: Percentage area under different potato varieties the study areas

It could be seen from the results that a majority of farmers (40.8\%) use Bhura aloo which is actually a mix of many red skinned local potato cultivars. Nearly one fourth of total respondents adopted improved red skinned variety Kufri Sindhuri. Kufri Pukhraj, Kufri Jyoti and Kufri Lalit were adopted by small number of farmers. When intensity of adoption was analyzed, it was found that area under Bhura aloo was highest (33\%) followed by Kufri Sindhuri (27.7\%), Kufri Pukhraj (12.64\%) and others.
Thus, it could be seen that red skin varieties were very popular among farmers and covered more than three fourth of total area. Only white skin variety Kufri Pukhraj had significant area under cultivation.

This finding complemented the fact that large gap in yield is prevalent due to cultivation of local varieties of potato by farmers. Improved varieties developed by ICAR institute viz. Kufri Sindhuri, Kufri Pukhraj, Kufri Jyoti and Kufri Lalit could give more yields as compared to local cultivars. Therefore, in order to bridge the existing yield gap in study area, adoption rate of improved varieties need to be enhanced. Local cultivars should be replaced by high yielding varieties by making farmers aware about the benefits of new varieties over older ones. This can be done through organization of training, laying out of Front Line Demonstrations and other awareness programmes as well as supply of quality seed of improved potato varieties.

\section{Technological gap of important production inputs}

Potato crop uses a lot of nutrients like nitrogen, phosphorus and potash for per unit area to provide high yield. The yield level also depends on other inputs like quantity of seed and pesticides used for control of disease and pests. Therefore, actual level of inputs used by farmers and the technological gap of farmers were analyzed (Table 3). Results revealed that overall technological gap per unit area was highest in case of use of potassium fertilizer (35.4\%) followed by nitrogenous fertilizers (27.6\%). Negative gap was observed in case of phosphorus use as farmers reported use of higher doses of phosphatic fertilizers (110 kg/ha) and plant protection chemicals $(3.7 \mathrm{~kg} / \mathrm{ha})$ than recommended level. These results were in confirmation with the results found during study of potato crop in Bihar by Singh and Rai (2011). As far as quantity of seed per unit area (seed rate) is concerned, overall farmers used almost same quantity of seed as the recommended level of $2.5 \mathrm{t} /$ ha. Therefore, gap in seed use was minimum at 2.2 per cent only. Input use was also studied among different category of farmers. It was observed that large farmers used recommended seed rate with minimum gap $(0.16 \%)$ while marginal farmers used lower seed rate. All categories of farmers used lower than recommended dose of nitrogen with a gap ranging from 27.4 to 31.6 per cent. Pesticide use 
Table 3: Level of material input use and technological gap of sampled farmers $(\mathrm{N}=90)$

\begin{tabular}{|c|c|c|c|c|c|c|c|c|c|}
\hline \multirow{2}{*}{ Particulars } & \multirow{2}{*}{$\begin{array}{l}\text { Recommended } \\
\text { dose* }\end{array}$} & \multicolumn{2}{|c|}{$\begin{array}{c}\text { Marginal Farmers } \\
\quad(<1 \text { ha })\end{array}$} & \multicolumn{2}{|c|}{$\begin{array}{c}\text { Small Farmers } \\
\text { (1-2 ha) }\end{array}$} & \multicolumn{2}{|c|}{$\begin{array}{l}\text { Large farmers } \\
\quad(>2 \text { ha })\end{array}$} & \multicolumn{2}{|l|}{ Overall } \\
\hline & & $\begin{array}{l}\text { Actual } \\
\text { input use }\end{array}$ & Gap & $\begin{array}{l}\text { Actual } \\
\text { input use }\end{array}$ & Gap & $\begin{array}{l}\text { Actual } \\
\text { input use }\end{array}$ & Gap & $\begin{array}{l}\text { Actual } \\
\text { input use }\end{array}$ & Gap \\
\hline Seed (Kg/ha) & 2500 & 2348 & $\begin{array}{l}152 \\
(6.08)\end{array}$ & 2558 & $\begin{array}{l}-58 \\
(2.32)\end{array}$ & 2504 & $\begin{array}{l}-4.0 \\
(0.16)\end{array}$ & 2445 & $\begin{array}{l}55 \\
(2.20)\end{array}$ \\
\hline Nitrogen $(\mathrm{Kg} / \mathrm{ha})$ & 150 & 108.93 & $\begin{array}{l}41.07 \\
(27.38)\end{array}$ & 111.83 & $\begin{array}{l}38.17 \\
(25.44)\end{array}$ & 102.57 & $\begin{array}{l}47.43 \\
(31.62)\end{array}$ & 108.56 & $\begin{array}{l}41.44 \\
(27.62)\end{array}$ \\
\hline Phosphorus (Kg/ha) & 90 & 107.87 & $\begin{array}{l}-17.87 \\
(-19.85)\end{array}$ & 117.47 & $\begin{array}{l}-27.47 \\
(-30.52)\end{array}$ & 103.53 & $\begin{array}{l}-13.53 \\
(-15.03)\end{array}$ & 110.0 & $\begin{array}{l}-20.00 \\
(-22.23)\end{array}$ \\
\hline Potassium (Kg/ha) & 100 & 65.35 & $\begin{array}{l}34.65 \\
(34.65)\end{array}$ & 68.72 & $\begin{array}{l}31.28 \\
(31.28)\end{array}$ & 56.46 & $\begin{array}{l}43.54 \\
(43.54)\end{array}$ & 64.62 & $\begin{array}{l}35.38 \\
(35.38)\end{array}$ \\
\hline $\begin{array}{l}\text { Plant protection } \\
\text { chemical (Kg/ha) }\end{array}$ & 2.0 & 3.63 & $\begin{array}{l}-1.63 \\
(-81.5)\end{array}$ & 3.48 & $\begin{array}{l}-1.48 \\
(-74.0)\end{array}$ & 4.14 & $\begin{array}{l}-2.14 \\
(-107.0)\end{array}$ & 3.68 & $\begin{array}{l}-1.68 \\
(-84.0)\end{array}$ \\
\hline
\end{tabular}

*Source: Department of Agriculture, Govt. of Bihar (www.krishi.bih.nic.in);

Note: 1. Figures in parentheses indicate the gap in percentage; 2. Negative sign (-) indicates the excessive use of inputs by farmers; 3 . Dose of chemical used to control late blight disease in potato is taken as recommended plant protection measure.

was found to be very high among farmers and large farmers used more than double of the recommended dose of pesticides. Phosphorus use was also 15-30 per cent higher than required dose.

Use of higher doses of pesticides and phosphorus by potato growers may be on account of lack of awareness and knowledge about ill effects of these chemicals on plant, soil and environment. Therefore, awareness programmes should be organized in study area in order to control rampant use of chemical pesticides.

\section{CONCLUSION}

Generally, potato yield realized on the farmer's field is considerably lower than that recorded on the demonstration plot. Bihar faces the problem of low productivity and thus, high yield gap in potato production despite having highly fertile land and ample water availability for irrigation. This study revealed that total yield gap of 43.4 per cent exists in potato in Vaishali and Saran district of Bihar. Since red skinned local potato cultivar commonly called 'Bhura aloo' was predominantly grown in this region, the yield level was low. If farmers would adopt high yielding improved varieties viz. Kufri Sindhuri, Kufri Lalit, Kufri Pukhraj, Kufri Ashoka etc, the existing yield gap could be bridged to a large extent. Lack of awareness about correct doses of fertilizer application, imbalanced use of NPK and lack of potash application were other major reasons of low productivity in the study area. Rampant use of pesticides was observed in the study areas which is a cause of concern for policy makers. In order to protect soil and environment from harmful chemical pollution, farmers must be made aware about ill effect of these chemicals. The yield gap may also be attributed to the fact that farmers used farm saved seed for a long period of time and late planting of potato due to water logging condition in some areas. Farmers would also require effective extension services to enable them to use recommended level of fertilizers and pesticides.

\section{REFERENCES}

Central Potato Research Institute (CPRI). 2017. Annual Report 2017. ICAR-Central Potato Research Institute, Shimla, Himachal Pradesh, India.

Central Potato Research Institute (CPRI). 2015. Vision 2050. Central Potato Research Institute, Shimla, Himachal Pradesh, India.

Chand, R. 2017. Doubling Farmer's Income: Rationale, Strategies, Prospects and Action plan, NITI Policy paper No. 1/2017, NITI Aayog, Govt. of India.

Department of Agriculture Cooperation and Farmers Welfare (DAC\&FW). 2018. Monthly Report Potato (January, 2018). Horticulture Statistics Division, Ministry of Agriculture and Farmers Welfare, Govt. of India.

Devaux, A., Kromann, P. and Ortiz, O. 2014. Potatoes for Sustainable Global Food Security, Potato Res., 57: 185-199.

Haverkort, A.J. and Struik, P. C. 2015. Yield levels of potato crops: Recent achievements and future prospects, Field Crops Res., 182: 76-85. 
$\underset{\text { AESSRA }}{\mathbb{U}^{\prime}}$ Singh et al.

Licker, R., Johnston, M., Foley, J.A., Barford, C., Kucharik, C.J., Monfreda, C. 2010. Mind the gap: how do climate and agricultural management explain the 'yield gap' of croplands around the world?, Glob. Ecol. Biogeog., 19: 769-782.

Lobell, D.B., Cassman, K.G. and Field, C.B. 2009. Yield Gaps: their importance, magnitudes and causes, Annu. Rev. Environ. Resour., 34: 179-204.

Ministry of Home Affairs (MHA). 2011. Census of India 2011: Rural-urban distribution of population. Ministry of Home Affairs, Government of India, New Delhi, India.

Ray, G.L., Chatterjee, P. and Banerjee, S.N. 1995. Technological Gap and Constraints in Agricultural Technology Transfer. Naya Prakash, Calcutta, India, pp. 95.

Sadras, V.O., Cassman, K.G. and Grassini, P. 2015. Yield gap analysis of field crops: Methods and case studies. FAO, Rome, Italy.
Singh D.K., Pandey, N.K. and Kharumnuid, P. 2018. An economic analysis of marketing of potato from Shimla hills of Himachal Pradesh, Economic Affairs, 63(2): 419-424.

Singh, S.K. and Rai, R.P. 2011. The potato crop in Bihar: Status and future challenges, Optimizing Crop Nutrition, Research Findings, e-ifc No. 27, International Potash Institute.

Singh, S.P. 2015. Growth performance and yield gap analysis of sugarcane in Bihar, India. (Doctoral Thesis). Banaras Hindu University, Varanasi, India.

Sinha, A.K. and Singh, S.K. 2019. Economics of Potato Production in Northern Hills of Chhattisgarh, Economic Affairs, 64(1): 01-07. 